\title{
POLITICAL DISCRIMINATION BY PRIVATE EMPLOYERS
}

\section{R. George Wright}

\section{INTRODUCTION}

In general, private employers are not legally prohibited from discriminating against current and prospective employees on the basis of political beliefs. ${ }^{1}$ But there are exceptions to this rule, within the United States $^{2}$ and internationally. ${ }^{3}$ This Article examines the persuasiveness and the limitations of the general rule and its exceptions, with special attention to the current political polarization in the United States. ${ }^{4}$

Thus, this Article takes into account the increasing significance of partisan and ideological politics in typical private workplaces. ${ }^{5}$ Such developments must be placed in the broader context of the increasing importance of the explicit politicization and polarization of the culture beyond the workplace. ${ }^{6}$ These trends are partly institutional, ${ }^{7}$ but, as it turns out, they also cannot be understood apart from considerations of what we will call the basic epistemic or cognitive virtues and vices. ${ }^{8}$

Throughout, the Article recognizes the advantages, costs, and risks associated with adopting a general rule intended to protect current and prospective employees from a private employer's discrimination on the basis of politics. ${ }^{9}$ In the final section, ${ }^{10}$ this Article argues that, particularly in light of our political and cultural circumstances, recognizing a general right of private employees to be free from employer discrimination based on politics would be unworkable and

* Lawrence A. Jegen Professor of Law, Indiana University Robert H. McKinney School of Law.

1. See Section II. This Article will not specifically address political discrimination in the context of private university faculty decisions, given the current uncertainties over the basic functions of such universities. For background, see R. George Wright, Campus Speech and the Functions of the University, 43 J. COLLEGE \& UNIV. L. 1 (2017). Private employers such as political party organizations and ideological think tanks present special problems as well. Not-for-profit private employers, outside the above categories, fall within the scope of this Article. Labor union organizing rights of employees are addressed below only tangentially, as are relations between corporate employers and their customers. For a broader survey of ways in which a private workplace might be thought of as a form of government, see Elizabeth Anderson, Private Government: How Employers Rule Our Lives (and Why We Don't Talk About It) (2017).

2. See infra Section II.

3. See id.

4. See infra Sections III-VI.

5. See infra Section III.

6. See infra Section IV.

7. See infra Sections IV $-\mathrm{V}$.

8. See infra Section $V$

9. See infra Sections II. - VI.

10. See infra Section VI. 
otherwise ill-advised. ${ }^{11}$ This Article concludes against recognizing such a right, not despite — but largely because of — our polarized politics.

\section{CASe Law Recognizing a Right Against PoliticaL DISCRIMINATION BY PRIVATE EMPLOYERS}

Typically, private employees and job applicants are not legally protected from employer discrimination on grounds of political belief and the expression thereof. ${ }^{12}$ There are, however, a growing number of exceptions to this basic rule. ${ }^{13}$ Some of these exceptions are newly emerging, ${ }^{14}$ and others are well-established. ${ }^{15}$

Among the well-established exceptions to the general rule are the protections embodied in the California Labor Code. ${ }^{16}$ The California Labor Code provides, in part, that:

[n]o employer shall make, adopt, or enforce any rule, regulation or policy: (a) Forbidding or preventing employees from engaging or participating in politics ... (b) Controlling or directing, or tending to control or direct the political affiliation of employees. ${ }^{17}$

11. Among the constitutionally important areas unaddressed herein are the public employer political patronage cases, the public employee free speech cases, and the cases in which state law treats private business spaces as akin to a governmental or public forum. Among the public employer patronage cases, see, e.g., Hefernan v. City of Paterson, N.J., 136 S. Ct. 1412, 1416 (2016) (government employer's incorrect belief that a demoted employee had supported an opposing candidate); O'Hare Truck Serv., Inc. v. City of Northlake, 518 U.S. 712 (1996) (involving an outside contractor with the government, as distinct from a typical government employee); Rutan v. Republican Party, 497 U.S. 62, 66 (1990) (involving selective exceptions to a government hiring freeze); Branti v. Finkel, 445 U.S. 507, 518 (1980) (focusing on party affiliation's relationship to effective job performance, as distinct from focusing on the public employee's policymaking or confidential role); Elrod v. Burns, 427 U.S. 347, 373 (1976) (holding "the practice of patronage dismissals . . unconstitutional under the First and Fourteenth Amendments"). Among the public employee free speech cases, see, e.g., Lane v. Franks, $134 \mathrm{~S}$. Ct. 2369, 2378 (2014) (public employee's compelled trial testimony as protected speech); Garcetti v. Ceballos, 547 U.S. 410,427 (2006) (speech within the scope of the government employee's job responsibilities as unprotected); Connick v. Myers, 461 U.S. 138, 147-48 (1983) (speech must be on a matter of public interest and concern to qualify for protection); Pickering v. Bd. of Educ. of Township High School Dist. 205, 391 U.S. 563, 568 (1968) (balancing the respective employer and employee or public interests at stake in public employee speech cases). Among the cases treating private business spaces as akin to publicly owned property, see, e.g., Pruneyard Shopping Ctr. v. Robins, 447 U.S. 74 (1980) (decided under California state constitutional law); Glovsky v. Roche Bros., 469 Mass. 752, 758 , 17 N.E.3d 1026, 1031-32 (2014) (nomination signature solicitation on a store's private property held to be functionally akin to a traditional public speech forum).

12. See infra notes $16-40$ and accompanying text.

13. See infra notes $41-60$ and accompanying text.

14. See id.

15. See, e.g., infra notes $16-18$ and accompanying text.

16. See, in particular, Cal. Labor Code $\S \S 1101-02$ (West 2017) (initially adopted 1937).

17. Id. at $\S 1101$. 
The Labor Code then further provides that:

[n]o employer shall coerce or influence or attempt to coerce or influence his employees through or by means of threat of discharge or loss of employment to adopt or follow or refrain from adopting or following any particular course or line of political action or political activity. ${ }^{18}$

Unsurprisingly, the California Labor Code does not seek to clearly specify the boundaries of what is and what is not "politics," or the realm of the "political." 19 In the absence of a likely unobtainable precise and general definition of the "political," the courts interpreting the scope of the relevant California Labor Code sections have usually adopted a broadly inclusive approach. ${ }^{20}$

The most useful California case discussing the relevant Labor Code provisions is Gay Law Students Association v. Pacific Telephone \& Telegraph $\mathrm{Co}^{21}$ This case was brought on several distinct theories, ${ }^{22}$ including an alleged violation of California Labor Code sections 1101 and 1102 by the defendant employer. ${ }^{23}$ The court construed these sections as intending "to protect the fundamental rights of employees in general to engage in political activity without interference by employers." 24

The court ultimately adopted a relatively broad understanding of what should count, in the relevant statutory context, as the realm of the political. ${ }^{25}$ In particular, the statutory sections in question could not be "narrowly confined to partisan activity," 26 or to distinctly electoral activity. ${ }^{27}$ In the statutory context, the "political" encompasses causes as well as candidates, ${ }^{28}$ along with some instances of litigation, ${ }^{29}$ symbolic

\footnotetext{
18. Id. at $\$ 1102$. No other possible employer sanctions of an employee are addressed herein.

19. See id. at $\$ \$ 1101-05$. For a sense of the contested scope of what should count as "political," outside of the obvious central contexts, see infra Section IV.

20. See, e.g., Smedley v. Capps, Staples, Ward, Hastings \& Dodson, 820 F. Supp. 1227, 1229 (N.D. Cal. 1993). The court in Smedley, however, opined that "it is by no means certain that discussions of lesbianism with clients of [plaintiff's law] firm at firm social events are political activities." Id. at 1230.

21. 24 Cal. $3 \mathrm{~d} 458,595$ (1979).

22. See generally id.

23. Id. at $486-87$.

24. Id. at 487 (quoting Fort v. Civil Serv. Com'n, 61 Cal. 2d 331, 335 (1964))

25. See id

26. $I d$.

27. See id.

28. See id

29. See id
} 
speech, ${ }^{30}$ and "association with others for the advancement of beliefs and ideas." 31

On this understanding, the advocacy of gay employment rights was recognized as "political" within the meaning of the statute. ${ }^{32}$ In particular, the aims and tactics of indisputably political movements, including those seeking racial or gender equal employment opportunity, ${ }^{33}$ were said to sufficiently resemble those of the plaintiff Gay Law Students Association and other groups. ${ }^{34}$ Thus, the California Supreme Court concluded that the Gay Law Students Association had adequately alleged violations of Labor Code sections 1101 and 1102 by defendant employer Pacific Telephone \& Telegraph Co. ${ }^{35}$

This California statutory protection against employment discrimination has been held to apply to public as well as private employers, ${ }^{36}$ and to apply with respect to job applicants as well as current employees. ${ }^{37}$ Among the contestable issues under the statute is whether the plaintiff must show not only the employer's interference with the plaintiff's political activity, but, in addition, that the employer's motivation in doing so was also political, rather than merely inadvertent or non-political. ${ }^{38}$ This issue is in turn related to that of the boundary line between employer discrimination on the basis of politics and the employer's right to place reasonable restrictions on an employee acting in his or her "official capacity" 39 as a representative of the employer. ${ }^{40}$

30. See id.

31. Id. Classically, the "political" involved a natural association of persons who engage one another in speech and discussion bearing upon the prudent, the just, or upon good and evil more broadly. See Aristotle, Politics 1253 (Penguin rev. ed. 1981) ( 350 BCE) ("man is by nature a political animal").

32. Gay Law Students Ass' $n, 24$ Cal. 3d at 488.

33. See id.

34. See id.

35. Id. at 489 (citing Lockheed Aircraft Corp. v. Superior Court, 28 Cal. $2 d 481$ (1946)). The Lockheed court had held that section 1101 was not intended "to protect any individual or group advocating the overthrow of the government by force or violence. On the contrary, the words 'politics' and 'political' imply orderly conduct of government, not revolution." Lockheed, $28 \mathrm{Cal}$. $2 \mathrm{~d}$ at 485.

36. See, e.g., Campbell v. Regents of Univ. of Cal., 35 Cal. 4th 311, 330 (2005).

37. See Gay Law Students Ass' $n, 24$ Cal. 3d at 487 n. 15.

38. See, e.g., Couch v. Morgan Stanley \& Co., 656 Fed. Appx. 841, 842-43 (9th Cir. 2016).

39. See, e.g., Abbey v. Mothers Against Drunk Driving, 1993 WL 559688 at 16 (E.D. Cal. 1993) (unreported decision) (citing California cases).

40. Among the apparently unresolved issues is whether the Labor Code causes of action generally require a plaintiff to have exhausted available administrative remedies. Contrast Couch v. Morgan Stanley, Co., 2014 WL 1577463 at 6 (E.D. Cal. 2014) (unreported decision) (citing the newly enacted California Labor Code $\$ 244$ (a) (2014)) (apparently disclaiming any administrative exhaustion requirement) (citing cases) with Mungo v. Hazel Hawkins Mem. Hosp., 2017 WL 2289222 (N.D. Cal. May 25, 2017), slip op. at 12 (requiring administrative exhaustion prior to suit). Among other United States jurisdictions, see, e.g., Oregon's Worker Freedom Act, S.B. 519 (effective January 1, 2010) (prohibiting worker dismissals for failure to attend an otherwise mandatory meeting at which the employer expresses its own political views). This statute is discussed in Paul M. Secunda, Addressing 
California leads American jurisdictions generally in these respects. On a much broader scale, the European Court of Human Rights has also been open to the idea of a right to political non-discrimination by private employers. ${ }^{41}$ The strength of such an employee right, however, may be limited or variable, depending upon context. ${ }^{42}$ The leading European case to this point is Redfearn v. United Kingdom. ${ }^{43}$

In this case, the complainant, Redfearn, was briefly employed as a driver's escort and then as a driver by Serro Ltd., a private entity. ${ }^{44}$ Redfearn's job responsibilities included transporting persons with disabilities, most of whom were of Asian origin, within the local area. ${ }^{45}$ There had, for a time, been no complaints as to Redfearn's job performance. ${ }^{46}$ Redfearn, however, then ran for local electoral office and was chosen to serve as local councilor for the British National Party $(\mathrm{BNP}){ }^{47}$

At that point, Redfearn's employer, Serro Ltd., dismissed him on several related grounds. ${ }^{48}$ Crucially, the BNP was, at the time, open to membership only for whites, and had adopted an anti-integrationist and anti-nonwhite immigration policy. ${ }^{49}$ Serro's dismissal of Redfearn cited "potential health and safety risks as [Redfearn's] continued employment would give rise to considerable anxiety among passengers and their caregivers." ${ }^{" 50}$ Serro also "expressed concern that [Redfearn's] continued employment could jeopardize its reputation and possibly lead to the loss of its contract with the [local] city council." 51

In addressing Redfearn's grievance, the European Court of Human Rights relied crucially on Article II of the European Convention of Human Rights. ${ }^{52}$ Article II provides in part that "[e]veryone has the right to freedom of peaceful assembly and to freedom of association

Political Captive Audience Workplace Meetings in the Post-Citizens United Environment, 120 YALE L.J. ONLINE 17 (2010) (discussing some possible free speech issues therein raised). See also, e.g., New Mexico Stat. Ann. § 1-20-13 (West 2018) (criminalizing employer coercion of employees in the context of voting); Lisa B. Bingham, Employee Free Speech in the Workplace: Using the First Amendment as Public Policy for Wrongful Discharge Actions, 55 OHIO ST. L.J. 341 (1994).

41. See, e.g., Redfearn v. United Kingdom, [2012] Eur. Ct. H.R. 1878 (2012).

42. See id. at IIII $29,44,47$.

43. See Redfearn, supra note 41 .

44. See id. at पIII 6-7.

45. See id. at $\mathbb{I} 7$.

46. See id.

47. See id. at IIII 8-11.

48. See id. at II 11 .

49. See id. at $\mathbb{T} 9$.

50. Id. at II 11.

51. Id.

52. See Convention for the Protection of Human Rights and Fundamental Freedoms art. 11, opened for signature Nov. 4, 1950, 213 U.N.T.S. 221 (entered into force Sept. 3, 1953). 
with others." 53 Importantly, this formulation is immediately qualified, with the right being subject to such restrictions "as are prescribed by law and are necessary in a democratic society in the interests of security or public safety, for the prevention of disorder or crime, for the protection of health or morals, or for the protection of the rights and freedoms of others." 54

The European Court of Human Rights recognized the absence of direct and specific governmental action in the Redfearn case. ${ }^{55}$ The Court declared, however, that "there is . . a positive obligation on the authorities to provide protection against dismissal by private employers where the dismissal is motivated solely by the fact that an employee belongs to a particular political party." 56 The required positive governmental protection is, however, again limited by the various interests and right-balancing considerations built into Article II itself. ${ }^{57}$ A more or less open-ended balancing test, ${ }^{58}$ or some version of what is called proportionalism, ${ }^{59}$ is thus to be applied in the employer political discrimination cases. ${ }^{60}$

53. Id. at art. (1). Northern Ireland's protection from politically based discrimination is relatively broad, with the chief exception being for promoting political violence in the Northern Ireland context. See the useful discussion by Eileen Lavery, Discrimination on the Ground of Political Opinion, www.equalityni.org/blog/articles/April-2017/Discrimination.

54. Convention, supra note 52, at 11(2).

55. See Redfearn, supra note 41 , at $\mathbb{\text { II }} 43$.

56. See id. Some such protection may be available in the form of the Equality Act of 2010, as discussed in Bircham Dyson Bell, Discrimination for Political Affiliation in the UK (Jan. 31, 2013), www.lexology.com/library/detail; Nicola Brown, Protection from Discrimination on the Ground of Political Views (Nov. 27, 2012), www.lexology.com/library/detail.

57. See, supra note 54.

58. See id. along with Redfearn, supra note 41 , at $₫ 43$ (referring to a "proportionality" inquiry); $i d$. at 44 ("in certain circumstances an employer may lawfully place restrictions on the freedom of association of employees where it is deemed necessary in a democratic society"); id. at II 47 (referring to a fair interest balancing). For background on several forms of European constitutional proportionalism, see, e.g., Robert Alexy, Constitutional Rights, Balancing and Rationality, 16 Ratio Juris 131 (2003); Julian Rivers, Proportionality and Variable Intensity of Review, 65 CAMB. L.J. 174 (2006). For a critique, see, e.g., Francisco J. Urbina, A Critique of Proportionality, 57 Am. J. Juris. 49 (2012). See also Ronald Dworkin, Rights as Trumps, in Theories of Rights 152, 164 (Jeremy Waldron ed. 1984).

59. See the authorities cited supra note 58. The idea of a purported human right that is nevertheless readily subject to being balanced away on various grounds raises what we might call questions of the compossibility or mutual compatibility of rights. See Dworkin, supra note 58.

60. For commentary on the Redfearn case, see, e.g., Alan Boggs, Redfearn v. United Kingdom: Hard Case Makes Good Law, OXFord HuMAN RIGHTS HUB (Dec. 17, 2012), http://ohrh.law.ox.ac.uk/redfearn-v-united-kingdom-hard-case-makes-good-law; Hugh Collins \& Virginia Mantouvalou, Redfearn v. UK: Political Association and Dismissal, 76 MOD. L. REV. 909 (2013); George Letsas, Redfearn v. UK: Even Racists Have the Right to Freedom of Thought, UK CONSTITUTIONAL LAW ASSOCIATION (Nov. 13, 2012) https://ukconstitutionallaw.org. In other contexts, see Grainger PLC v. Nicholson, [2009] UKEAT 0219_09_0311 (2009) (in an employment context, “[a] belief in man-made climate change, and the alleged resulting moral imperatives, is capable, if genuinely held, of being a philosophical belief for the purpose of the 2003 Religion and Belief Regulations. The belief must be of a similar cogency or status to a religious belief") (emphasis in the original). Relatedly, 
In contrast to Redfearn, and to successful California employees, consider the unresolved California case involving James Damore, ${ }^{61}$ who was dismissed from his employment as an engineer at Google, Inc. Damore circulated a controversial memo addressing Google's employment practices. $^{62}$ Damore filed a class action complaint in California state $\operatorname{court}^{63}$ on a number of grounds, including alleged violations of California Labor Code sections 1101 and 1102, as discussed above. ${ }^{64}$

Damore's initial presentation of a federal labor law claim ${ }^{65}$ to the National Labor Relations Board (NLRB) was unavailing. The Associate General Counsel's Advice Memorandum crucially emphasized language from Google's memorandum accompanying its discharge of Damore. ${ }^{66}$ Google's memorandum concluded in particular that Damore's post ${ }^{67}$ had

advanced and relied on offensive gender stereotypes to suggest that women cannot be successful in the same kinds of jobs at [the Employer] as men ... I want to make clear that our decision is based solely on the part of your post that generalizes and advances stereotypes about women versus men ... I also want to be clear that this is not at all about your expressing yourself on political issues or having political views that are different than others at the company. Having a different political view is absolutely fine. Advancing gender stereotypes is not. ${ }^{68}$

The Advice Memorandum observed that for the sake of diversity and

see Lucy Vickers, Religion and Belief Discrimination in Employment-the EU Law (Nov. 2006), relandbel_en.pdf.

61. See, e.g., Daisuke Wakabayashi, Google Legally Fired Diversity Memo Author, Labor Agency Says, THE NEW YORK TMES (Feb. 16, 2018) www.nytimes.com/2018/02/16/business/googlememo-firing.html. For commentary, see, e.g., Matthew Bodie, Analyzing James Damore's Employment Related Claims Against Google, ON LABOR (Aug. 18, 2017) https://law.emory.edu/ecgar/perspectives/volume--5/perspectives/google-political-discrimination .

62. The text of the Damore memo in question, entitled Google's Ideological Echo Chamber: How Bias Clouds Our Thinking About Diversity and Inclusion, is available at www.documentcloud.org/documents/3914586-Googles-Ideological-Echo-Chamber (July 2017).

63. See Damore v. Google LLC, First Amended Class Action Complaint, Case No. 18CV32159 (Santa Clara Sup. Ct., filed April 18, 2018).

64. See, supra notes 16-40, and accompanying text.

65. This claim was brought pursuant to the National Labor Relations Act, and in particular, 29 U.S.C. \$158(a) (1) (West 2017), addressing employer interference with protected rights of workers to engage in collective bargaining and other forms of mutual aid. See 29 U.S.C. $\$ 157$ (West 2017).

66. See Jayme L. Sophir, Associate General Counsel, Advice Memorandum of January 16, 2018, www.scribd.com/document/371739304 [hereinafter Advice Memorandum].

67. For an expression of Damore's views, see Damore, supra note 62.

68. Advice Memorandum at 3. 
effective overall job performance, ${ }^{69}$ "employers must be permitted to 'nip in the bud' the kinds of employee conduct that could lead to a 'hostile workplace' rather than waiting until an actionable hostile workplace has been created before taking action." ${ }^{70}$ In the case at hand, "[n]umerous employees [had] complained to the Employer that the memorandum was discriminatory against women, deeply offensive, and made them feel unsafe at work." 71

On this basis, the Advice Memorandum concluded, as to the Federal National Labor Relations Act (NLRA) claim, ${ }^{72}$ that Damore's memo "included both protected and unprotected statements, and that the Employer discharged [Damore] solely for unprotected statements." "73 The Advice Memorandum did not address other possible theories of violation and recovery. ${ }^{74}$

The Damore litigation against Google is currently unresolved. Overall, the limited case law endorsing an employee's right against political discrimination by a private employer does not begin to reflect the contemporary level of concern over literal workplace politics. ${ }^{75}$

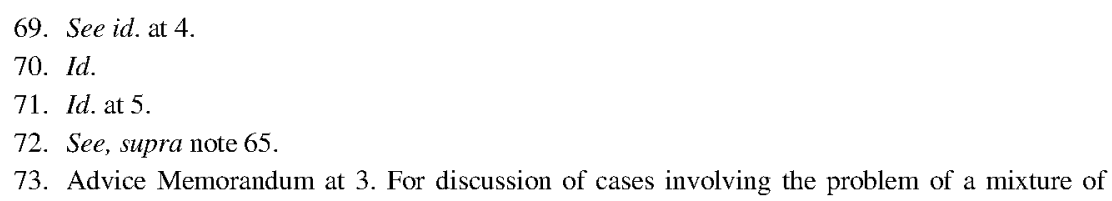

73. Advice Memorandum at 3. For discussion of cases involving the problem of a mixture of statutorily permissible and impermissible employer motives, see Price Waterhouse v. Hopkins, 490 U.S. 228 (1989), superseded by statute on other grounds per Burrage v. United States, 134 S. Ct. 881 (2014) (citing the Civil Rights Act of 1991, Pub. L. No. 102-106, 105 Stat. 1071, 1075, as codified at 42 U.S.C. $\S \S 2000 \mathrm{e}-2(\mathrm{~m})$ ); Desert Palace, Inc. v. Costa, 539 U.S. 90 (2003) (Title VII mixed motive plaintiff need not present direct evidence of discrimination); Mt. Healthy City Bd. of Educ. v. Doyle, 429 U.S. 274 (1977) (mixed motive First Amendment case, as distinct from a case involving a pretextual dismissal).

74. For a useful analysis, see Katherine Pickle, Why Google May Be in the Right: An Analysis of Political Discrimination in the Workplace, EMORY CORPORATE GOVERNANCE AND ACCOUNTABILITY REVIEW (2018) http://law.emory.edu/ecgar/perspectives/volume-5/perspectives/google-politicaldiscrimination, and in particular Section VI thereof on the constitutional controversiality of California Labor Code sections 1101 and 1102.

75. See, e.g., Politics in the Workplace: 2016 Election Season, AMERICAN Psychological Association Center for Organizational Excellence (Sep. 2016) www.apaexcellence.org/asets/general/2016-politics-workplace-survey-results.pdf; Political Talk Plagues Workers Months After U.S. Election, AMERICAN PsychologiCAL Association (May 3, 2017) www.apa.org/news/press/releases; David W. Ballard, Navigating Political Talk at Work, HARVARD BUSINESS REVIEW (Mar. 2, 2017) https://hbr.org/2017/03/navigating-political-talk-at-work; Donna Ballman, Can You Be Fired For Your Political Beliefs Or Activities? Maybe, HUFFINGTON POST (Dev. 6, 2017) www.huffingtonpost.com/donna-ballman/can-you-be-fired-for-your-b-9154066.html; Alexander Hertel-Fernandez, Employer Political Coercion: A Growing Threat, THE AMERICAN PROSPECT (Nov. 23, 2015) http://prospect.org/article/employer-political-coercion-growing-threat; Rebecca Knight, Should You Talk About Politics at Work?, HARVARD BUSINESS REVIEW (Sept. 26, 2016), https://hbr.org/2016/09/should-you-talk-about-politics-at-work?; Jenna McGregor, All the Office Talk About Politics Since Trump's Election is Stressing People Out, THE WashingTON Post (May 3, 2017), www.washingtonpost.com/news/on-leadership/wp/2017/05/03/all-the-talk-about-politics; Vercruysse Murray, The Thin Line Between Political and Hate Speech: What's Acceptable at Work, 26 Mich. EMP. L. LeTTer 2 (2015); Alina Tugend, Speaking Freely About Politics Can Cost You Your Job, 
Partisan and ideological politics in the workplace is increasingly a matter of general interest, as explored below.

\section{THE INCREASING SIGNIFICANCE OF PARTISAN AND IDEOLOGICAL POLITICS IN THE PRIVATE EMPLOYER WORKPLACE}

It is widely appreciated that what one might call literal workplace politics has taken on increasing practical importance in several respects. Politics in the workplace has always posed difficult issues of law and policy. In some contexts, for example, a crucial legal distinction may be drawn between "pure" political speech and political speech conveying a broadly motivated union organizational message. ${ }^{76}$ Employee political speech, on or off the job, may in some cases reflect adversely on the employer in the minds of customers and others. ${ }^{77}$ In other cases, an employee's dismissal supposedly on the grounds of the employee's political speech may be a pretext for, or mixed with, illicit employer motivations. ${ }^{78}$ An employer's own political speech may in some cases become evidence of improper motivation of an employee's dismissal. ${ }^{79}$

The effects of partisan or ideological politics in the private workplace seem to have shifted in important ways, especially within the past several years. For many private sector employees, electoral and other political discussions at the workplace result in "at least one negative outcome, such as reduced productivity, poorer work quality, difficulty getting work done, a more negative view of coworkers, feeling tense or stressed out, or increased workplace hostility." 80 Workers between the ages of 18-34 appear to be disproportionately affected in these respects. ${ }^{81}$ Interestingly, workers seem to be adversely affected, largely without regard to their own political viewpoint or partisan affiliation. ${ }^{82}$

Not surprisingly, politics in the workplace also sometimes results in greater bonding among some employees, ${ }^{83}$ perhaps along with increased

THE NEW YORK TIMES (Feb. 20, 2015), www.nytimes.com/2015/02/21/your-money/speaking-aboutpolitics. More broadly, see Eugene Volokh, Deterring Speech: When Is It "McCarthyism?" When Is It Proper?, 93 CAL. L. REV. 1413 (2005).

76. See Ballman, supra note 75 , at 2 .

77. See Volokh, supra note 75 , at 1431-32.

78. See Guerin, supra note 75, at 1. For background, see the cases cited supra note 73.

79. See Murray, supra note 75 , at 2.

80. See Political Talk, supra note 75 , at 1 ; Ballard, supra note 75 , at 2 . The survey result of those reporting at least one such effect after the 2016 elections was 40 percent, an increase of approximately half from the pre-2016 election level of 27 percent. See Political Talk, supra note 75, at 1.

81. See Politics in the Workplace Survey, supra note 75, at 1.

82. See id

83. See id.; McGregor, supra note 75 , at 1. 
avoidance of worker interaction. ${ }^{84}$ The net result, though, is often largely one of mutual alienation, distancing, and divisiveness at the workplace. $^{85}$

The potential for both increased but selective employee bonding and for divisive effects for workers is heightened when political speech by the employer is taken into account. Employers and general corporate speech rights have been validated and expanded, particularly in the wellknown Supreme Court case Citizens United v. Federal Election Commission. ${ }^{86}$ Importantly, employer speech rights now interact with increasingly sophisticated and detailed employer monitoring of employee behavior. ${ }^{87}$ Employers, for example, can typically check to see which employees have opened, or responded to, employer political e-mail messages. ${ }^{8} 8$

Further complicating matters is the increasing tendency for private employers to take corporate political stances, whether out of conviction or expedience. ${ }^{89}$ Corporate social responsibility, in its political dimension, may take on a positive or a negative emotional quality, and may variously reflect the initiative of shareholders, advertising agencies and publicists, employers, employees, legislators, or actual and potential consumers. ${ }^{90}$

84. See Politics in the Workplace Survey, supra note 75, at 2; Political Talk Plagues Workers, supra note 75 , at 3 (thereby "perpetuating an 'us versus them' mentality and driving a wedge between people").

85. Knight, supra note 75 , at 3 ; see also authorities cited infra note 84 .

86. 558 U.S. 310 (2010). Among the massive critical literature, see, e.g., Laurence H. Tribe, Dividing Citizens United: The Case v. The Controversy, 30 Const. CommEnT. 463 (2015) and the associated Symposium contributions.

87. See generally Hertel-Fernandez, supra note 75.

88. See id. at 2.

89. See id. for several examples of this phenomenon.

90. For background, see, e.g., THE OXFORD HANDBOOK OF CORPORATE SOCIAL RESPONSIBILITY (Andrew Crane et al., eds. 2009); Championing Change in the Age of Social Media, Sprout Social, https:/sproutsocial.com/insights/data/championing-change; 2016 Cone Communications Millennial Employee Engagement Study, CONE www.conecomm.com/research-blog/2016-millennial-employee; Martin Armstrong, America's Most Polarizing Brands, STATISTA (Oct. 25, 2017), www.statista.com/chart/11601/americas-most-polarizing; Mark Berger, Google Engineers Refused to Build Security Tool to Win Military Contracts, Bloomberg (June 21, 2018), www.bloomberg.com/news/articles/2018-06-21/google-engineers-refused; Aine Cain, As America Becomes More Polarized, Private Companies Are Getting Pushed into the Political Spotlight, Business INSIDER (Sept. 18, 2017), www.businessinsider.com/private-companies-politics-2017-8; Ian Marcus Corbin, Silicon Valley Has Entered the Culture War to 'Make the World a Better Place', SPECTATOR https://usa.spectator.eu.uk/2018/05/silicon-valley-has-entered; Ian Crouch, Keurig, Papa John's, and the Politicization of American Junk, THE NEW YORKER (Nov. 14, 2017), www.newyorker.com/culturedesk/keurig-papa-johns; Pamela N. Danziger, When Corporate Social Responsibility Veers into Political Action: Safe or Sorry?, FORBES (Mar. 12, 2018), www.forbes.com/sites/pamdanziger/2018/03/12/whencorporate; Ross Douthat, 'Woke' Corporations Still All About the Bottom Line, www.dispatch.com/opinion/20180303/ross-douthat-work; Nicole Hammer, Business Is Politics? Delta Shows How Corporations Are Part of America's Political Battles, Whether They Like It Or Not, THE 
Historically, it has often seemed sensible for corporate employers to avoid unnecessarily alienating any potentially valuable market demographic. As Michael Jordan famously, if apocryphally, once declared: "Republicans buy sneakers, too." 91 Increasingly though, corporate employers either wish to, or feel somehow pressured to, take distinct positions on one or more broad political issues. In the current political climate, it is certainly understandable that many people want corporations to promote specific political views that they themselves favor. $^{92}$ And it is equally understandable that many employees, or potential employees, ${ }^{93}$ want their employer to take political stances congruent with their own. ${ }^{94}$

There is, however, a difference between wishing one's own values to be promoted by one's employer, or by other corporations, and wishing merely that a corporate employer take some reasonable stance on political issues, whether opposed to one's own values or not. ${ }^{95}$ Wishing for greater business commitment to one's own side in a cultural or political conflict does not logically commit one to a similar wish with regard to the opposing side. ${ }^{96}$

Columbus DisPatch (Mar. 3, 2018), www.usnews.com/opinion/thomas-jefferson-street/articles/201802-27/deltas-nra; Brandon Hogan, Your Boycott Might Fail, But You Should Do It Anyway, The HUFFINGTON POST (Apr. 25, 2018), www.huffingtonpost.com/entry/opinion-hogan-boycott; Brian Hughes, Why Corporate Social Responsibility Is Essential For Brand Strategy, THE HuFFInGTON POST (Dec. 6, 2017), www.huffingtonpost.com/brian-hughes/why-corporate; Pierre Lemieux, Business Is Getting Too Politicized, FOUNDATION FOR ECONOMIC EDUCATION (Jan. 13, 2018), https://Fee.org/articles/business-is-getting; Julia Marsh, Judge: Bars Are Allowed to Throw Out Trump Supporters, NEW YORK POST (Apr. 25, 2018) https://nypost.com/2018/04/25/judge-bars; Mark Schaefer, Does Every Brand Need to Take a Political Stand?, www.businessesgrow.com/2018/02/15/political-stand; Andrew Ross Sorkin, BlackRock's Message: Contribute to Society, or Risk Losing Our Support, THE NEW YORK TIMES (Jan. 15, 2018), www.nytimes.com/2018/01/15/business/dealbook/blackrock; Eugene Volokh, Can Businesses Refuse to Serve--or Employ-Trump Supporters?, THE WASHINGTON POST (Nov. 25, 2016), www.washingtonpost.com/news/volokh/conspiracy/wp/2016/11/125/can-businesses; Phil Wahba, Starbucks to Encourage Baristas to Discuss Race Relations with Customers, FoRTUNE (Mar. 26, 2015) http://fortune.com2015/03/16/starbucks-baristas-race-talk.

91. For some complications, see Giri Nathan, Did Michael Jordan Ever Say "Republicans Buy Sneakers, Too?" DEADSPN (Jul. 29, 2016), https://deadspin.com/did-michael-jordan.

92. Those who wish for corporations to take a stand on environmental issues tend, presumably, to favor policies intended to enhance, rather than degrade, the environment. See 2016 Cone Communications, supra note 90 , at 2.

93. See id. (focusing in particular on millennial respondents).

94. See id.

95. Public opinion surveys, or their interpretations, may not always clearly distinguish between corporations promoting the respondent's own favored political values, and corporations embracing a range of political values, to some of which the particular respondent may be opposed. See, e.g., Championing Change, supra note 90 , at 3 ("c $[\mathrm{t}]$ wo thirds of consumers . . say it's important for brands to take public stands on social and political issues"); Cain, supra note 90, at 2 ("a majority of Americans are just fine with pushing businesses into the political arena").

96. See Corbin, supra note 90 , on corporate political stances as partially reflecting cultural wars by other means. See also Hughes, supra note 90, at 2 ("[h]aving a . . core message that resonates with 
To some extent, corporate political stances today are a version of familiar and often politically more controversial themes of corporate social responsibility. ${ }^{97}$ In its more recent incarnation, though, a complex system of corporate preferences based on political considerations arises in today's corporate politics. Thus, the rise of identifiable Democratic and Republican corporate brands, ${ }^{98}$ with corresponding corporate disavowals, posturing, marketplace boycotts, social media traffic, and corporate political endorsements and exclusions. ${ }^{99}$ To decline to take sides may be increasingly seen as itself an implicit choice among political sides. ${ }^{100}$

The general trend toward increasingly explicit corporate politicization has understandably evoked a variety of reactions. For some observers, this trend largely amounts to new forms of pursuing familiar corporate bottom-line profitability goals. ${ }^{101}$ Accordingly, it is said, corporate activism "increasingly exists to protect .. self-interest and . . . stinginess - to justify the ways of CEOs to cultural power brokers, so that those same power brokers will leave them alone in realms that matter more to the corporate bottom line." ${ }^{102}$ For others, corporate political initiatives are partly a response to the perceived inability or unwillingness of governments to responsibly address the future. ${ }^{103}$ Thus, "society is increasingly turning to the private sector, asking that companies respond to broader social challenges." 104 Yet, for other observers, some politically-opinionated corporations may actually have greater anxiety about offending portions of its potential customer base

your audience can be the key business differentiator").

97. See generally Oxford Handbook, supra note 90. For a brief critique of the logic and actual consequences of explicitly pursing corporate social responsibility, see Lemieux, supra note 90.

98. See Schaefer, supra note 90 , at 2 (listing the 30 currently most distinctly polarizing brands).

99. See, e.g., Volokh, supra note 90 , at 1; Marsh, supra note 90, at 1; Bergen, supra note 90, at 1; Danziger, supra note 90, at 2 ("companies like Enterprise, Allied Van Lines, Delta and United Airlines have stopped offering discounts to National Rifle Association members"). Partisan consciousness may increasingly affect close business and personal relations. See, e.g., Tali Sharot \& Cass R. Sunstein, Would You Go to a Republican Doctor?, THE New YoRK TIMES (May 24, 2018), www.nytimes.com/2018/05/24/opinion/sunday/politics-distorts-judgment.html?; Kari Paul, Democrats and Republicans Can't Even Use the Same Dating Apps Anymore, Market Watch (Nov. 8, 2017), www.marketwatch.com/story/liberals-and-conservatives.

100. See Danziger, supra note 90 , at 3-4.

101. See Douthat, supra note 90 , at 1 .

102. Id. See also Stephen Bainbridge, Woke Business: Putting the Nike-Kaepernick Ad Controversy into Context: The Problem of Social Justice Warrior CEOs, at 3, (Sept. 5, 2018) www.professorbainbridge.com/2018/09/woke-business ("brands like Nike have profit maximizing reasons for aligning themselves with woke coastal millennials, who are at the core of the supposedly most desirable marketing demographic").

103. See Sorkin, supra note 90 , at 2.

104. $I d$. 
than they often acknowledge. ${ }^{105}$

It is, however, impossible to understand contemporary employeremployee politics without a sense of the much broader polarized and increasingly politicized cultural context. Employer-employee politics reflects this broader context. We now turn to this essential broader context.

\section{THE INCREASING SIgNIFICANCE OF POLARIZATION AND EXPLICIT POLITICIZATION IN GENERAL}

It is widely thought that current levels of American political polarization are relatively high, ${ }^{106}$ though perhaps not unprecedentedly so. ${ }^{107}$ There may be substantial counterpressures against expressing hostility on the basis of, say, at least some demographic categories, but arguably less so on the basis of political affiliation. ${ }^{108}$ Some observers attribute this heightened political polarization to the rise of the Internet and social media "echo-chambers." ${ }^{109}$ But the evidence for this thesis is,

105. See Crouch, supra note 90 , at 3. See also id. at 3-4 (" $[\mathrm{t}]$ here is something grotesque, demoralizing, and entirely fitting, in the Trump era, about seeing Americans act out political grievances through the quotidian and joyless consumer products that populate our lives").

106. See, e.g., ALAN ABRAMOWITZ, THE GREAT REALIGNMENT: RACE, PARTY TRANSFORMATION, AND THE RISE OF DONALD TRUMP Xi, 5, 15, 17 (2018) (illustrating distinct features of this polarization); Pew Research Center, Political Polarization, 1994-2017, www.peoplepress.org/interactives/political-polarization-1994-2017; The Partisan Divide on Political Values Grows Even Wider, PEw RESEARCH CENTER (Oct. 20, 2017) www.people-press.org/2017/10/05/the-partisandivide (the partisan political divide on basic political values as first reaching record highs under the Obama presidency, and then growing even larger under the Trump presidency); Clare Foran, American Political Divide Intensified During Trump's First Year as President, www.theatlantic.com/politics/archive/2017/10/trump-partisan-divide; Frank Newport \& Andrew Dugan, Partisan Differences Growing on a Number of Issues, Gallup (Aug. 3, 2017), https://news.gallup.com/opinion/polling-matters/215210/partisan-differences-growing; Ilya Somin, The Disturbing Growth of Partisan Bias, THE WASHGINTON POST (Dec. 9, 2015), www.washingtonpost.com/news/volokh-conspiracy/wp/2015/12/09. See also Sam Peltzman, Polarizing Currents Within Purple America, SSRN (Aug. 30, 2018), https://papers.ssrn.com/sol3/papers.cfm?abstract_id=3235867.

107. See Tom Kertscher, Political Vitriol IS Bad These Days, But Experts Say It's Been Worse, POLITIFACT (Jan. 16, 2011), www.politifact.com/wisconsin/article/2011/jan/16/political-vitriol.

108. See Dana Milbank, America's New Cycle of Partisan Hatred, The Washington Post (Apr. 17, 2015), www.washingtonpost.com/opinions/americas-new-tribal-cycle-of-hatred (referring to Shanto Iyenegar \& Sean J. Westwood, Fear and Loathing Across Party Lines, 59 AM. J. POL. ScI. 690, 703-04 (2014)); John Gramlich, Far More Americans Say There Are Strong Conflicts Between Partisans Than Between Other Groups in Society, PEw RESEARCH CENTER (Dec. 19, 2017) www.pewresearch.org/facttank/2017/12/19/far-more-americans. In the European context, see Sean J. Westwood et al., The Tie That Divides: Cross-National Evidence of the Primacy of Partyism, 57 EUR. J. POLITICAL RES. 333 (2018) (partisan hostility as greater than hostility on other grounds).

109. See, e.g., Nabeel Gilani, Me, My Echo Chamber, and I: Introspection on Social Media Polarization, (Mar. 5, 2018), https://arxiv.org/pdf/1803.01731.pdf; Cass R. Sunstein, The Law of Group Polarization, 10 J. POL. PHIL. 175 (2002). 
at best, incomplete. ${ }^{110}$

Increased political polarization may track a noticeable increase in what we might call group "sorting" 111 at a societal level. ${ }^{112}$ The basic idea is that "sorting," in the sense of being surrounded by like-minded persons, leads not merely to reinforcing one's beliefs, but toward greater extremism. ${ }^{113}$ One's political beliefs are held with more certitude, but they also tend to migrate toward a political extreme. And preference for like-minded company, across a range of issues, may be driven not only by a sense of one's own rightness, but by a sense of the harmfulness of one's designated political opponents as well. ${ }^{114}$

The effects of increased political polarization are amplified by expansions of what is thought to fall within the realm of the political. What is considered to be political, or "politicized," 115 can vary over

110. From among a substantial literature, see, e.g., Levi Boxell, The Internet, Social Media, and Political Polarization VOX (Oct. 1, 2017), https://voxeu.org/article/internet-social-media-and-politicalpolarisation. Interestingly, polarization seems to have increased the most among those least exposed to the Internet and social media in general. See Levi Boxell, Matthew Gentzkow \& Jesse Shapiro, Greater Internet Use Is Not Associated with Faster Growth in Group Polarization Among US Demographic Groups, PNAS (Oct. 3, 2017) www.pnas.org/context/early/2017/09/18.

111. See Emily Badger \& Niraj Chokshi, How We Became Bitter Political Enemies, THE NEW YORK TIMES (June 15, 2017), www.nytimes.com/2017/06/15/upshot/how-we-became. The crucial cite is to BILL BISHOP \& ROBERT CUSHING, THE BIG SORT (2009).

112. Questions of the direction, or directions, of causation regarding group sorting, the processes and increasing polarization may well be complex. See generally LILLIANA MASON, UNCIVIL AGREEMENT: HOW POLITICS BECAME OUR IDENTITY (2018).

113. See David Blankenhom, The Top 14 Causes of Political Polarization, THE AMERICAN INTEREST, at 2 (May 16, 2018), www.the-american-interest.com/201805/16/the-top-14-causes; Will Wilkinson, A Tale of Two Moralities, Part One: Regional Inequality and Moral Polarization, NISKANEN CENTER (Jan. 19, 2017), https://niskanencenter.org/blog/tale-two-moralities ("Americans have been sorting themselves along ideological lines into like-minded regions of the country"); Richard Florida, America's 'Big Sort' Is Only Getting Bigger, CityLaB (Oct. 25, 2016), www.citylab.com/equity/2016/10/the-big-sort-revisted. But see Samuel J. Abrams \& Morris P. Fiorina, The Myth of the "Big Sort", HoOver INSTITUTION (Aug. 13, 2012), www.hoover.org/research/mythbig-sort (noting some homogenizing tendencies, while also not denying increased cultural "inbredness" and "mutual incomprehension"); Morris Fiorina, Do Partisans Hate Each Other More than Ever?, REASON (Nov. 2018) https//reason.com//archives/2018/10/28/do-partisans-hate-each-other (reviewing Lilliana Mason, UnCivil Agreement: How Politics Became Our IDENTity (2018)).

114. See Hannah Fingerhut, Why Do People Belong to a Party? Negative Views of the Opposing Party Are a Major Factor, PEW RESEARCH CENTER, at 1, (Mar. 29, 2018) www.pewresearch.org/fact$\operatorname{tank} / 2018 / 03 / 29 /$ why-do-people-belong. See also Anup Gupta, When Political Ideology Undermines Logical Reasoning 3, SOCIETY FOR Personality AND Social Psychology (Oct. 12, 2016), www.spsp.org/news-center/blog/political-ideology-undermines-logic ("liberals find liberal arguments sounder, and conservatives find conservative arguments sounder, regardless of the actual soundness of the argument ")(emphasis in the original).

115. The idea of 'politicization' itself is thought of in multiple ways. See, e.g., Warren J. Samuels, Two Concepts of "Politicization," 55 SociaL SCI. 67 (1980); Samuel Hammond, The Future of Liberalism and the Politicization of Everything, NiSkANEN CENTER (Jan. 29, 2017), https://niskanencenter.org/blog/future-liberalism; Jennifer Szali, Why Is 'Politicization' So Partisan?, THE NEw YORK TIMES (Oct. 17, 2017) www.nytimes.com/2017/10/17/magazine/why-is-politicizationso-partisan.html. 
time. Beginning in the late 1960 s, for example, it was said that "the personal is political."16 The Critical Legal Studies movement simultaneously developed the argument that supposedly purely legal reasoning incorporates and reflects the political. ${ }^{117}$ More expansively, it is now urged that "everything is political." 118

Reactions to claims that everything is, or should be, political, in fact vary. ${ }^{119}$ Recognizing the political where we did not previously see it can be considered liberating even if, or because, new forms of conflict then follow. ${ }^{120}$ Other reactions, however, may involve distaste and regret. ${ }^{121}$ In any event, the broadening scope of what is said to fall within the scope of the political doubtless has many causes.

Among the most basic such causes, it seems, is the gradually increasing explicit politicization of the national economy. There is plainly more to the national economy than familiar market-place competition. The opportunities for what is called economic rent-seeking, through politics, have been increasing for some time. ${ }^{122}$ A corporate actor's prospective gains from lobbying for any sort of valuable status or legal privilege may well exceed their likely gains from genuinely productive activity that is more freely valued by consumers. ${ }^{123}$ In such

116. See Carol Hanish, The Personal Is Political (Feb. 1969), www.carolhanish.org/CHwritings/PIP.html (January 2006); Ralph Benko, The Political Is Now Personal, The HufFington Post (Feb. 18, 2018), www.huffingtonpost.com/living-roomconversations/the-political-is-now-personal.

117. See, e.g., Peter Gabel, What It Really Means to Say "Law is Politics": Political History and Legal Argument in Bush v. Gore, 67 BRoOK. L. REv. 1141, 1144 (2002) ("the court [in Bush v. Gore] made transparent what is usually mystified--the political nature of all legal reasoning").

118. See Hammond, supra note 115; The Politicization of Everything, THE WALL STREET JOURNAL (Sept. 24, 2017), www.wsj.com/amp/articles/the- politicization-of-everything-1506291118; Kevin Baker, The Politicization of Everything, Politico (Jan. 31, 2017), www.politico.com/magazine/story/2017/01/the-politicization-of-everything-214714. More tentatively, see Jean-Luc Nancy, Is Everything Political?, 2 New CenTENNIAL Rev. 15 (2002).

119. See Nancy, supra note 118 , at 15 ("the tone of the enunciation of the reception can be resigned, disconcerted, affirmative or contentious").

120. See the sources cited supra notes 116-118.

121. See, e.g., Michele Margolis, When Politicians Determine Your Religious Beliefs, THE NEW YORK TIMES (July 11, 2018) www.nytimes.com/2018/07/11/opinion/religion-republican-democrat.html; Conor Friedersdorf, Why Everything Is Politicized Even Though Most Americans Hate It, THE ATLANTIC (Mar. 26, 2013), www.theatlantic.com/politics/archive/2013/03/why-everything-ispoliticized; Emily Jashinsky, Poll: More Than 40 Percent Say Politicization of Sports and Entertainment Shows Has Made Them Less Likely to Watch, WASHINGTON EXAMINER (Mar. 21, 2018), www.washingtonexaminer.com/opinion/poll-more-than-40-percent.

122. Rent-seeking refers to organized activity aimed not at generally attracting appropriately willing buyers, but specifically at obtaining any sort of legal monopoly or enforceable privilege. See, e.g., Brink Lindsey \& Steve M. Teles, THE CAPTURED EConomy 18 (2017); RANDY T. Simmons, BEYOND POLITICS 193 (rev. 2d ed. 2011).

123. See Lindsey \& Teles, supra note 122, at 42; Eamonn Butler, Public Choice: A Primer 76-77 (2012); Susan E. Dudley \& Jerry Brito, Regulation: A PRIMER 71 (2012); Mancur Olson, The RISE AND DECLINE OF NATIONS 42 (1982) ("the organization can in principle serve its members either 
cases, seeking economic rents through one or another form of politics becomes more attractive. ${ }^{124}$ The focus of many persons, corporate or otherwise, turns increasingly toward politics, and the political stakes correspondingly become higher in this respect. ${ }^{125}$ Unhappily, any resulting increased economic inequality ${ }^{126}$ and generally slower economic growth ${ }^{127}$ in turn again increase the perceived importance of politics in general. The increasing importance of politics in this respect is self-reinforcing, and even self-exacerbating.

If we ultimately recognize any broad right of private employees against employer political discrimination, we must consequently recognize the increasing scope, intensity, conspicuousness, clarity, and practical stakes of what counts as political. At its most pervasive and extreme, politics understandably becomes something from which many persons seek some respite. Attempts to legally protect private employees, or to bind private employers, with regard to political discrimination would have to take this broad state of affairs into account.

Those who do not welcome the increasing scope, pervasiveness, and intensity of politics in general and in the private workplace in particular might suggest that political conflicts have taken on an increasingly severe prisoner's dilemma-type character. ${ }^{128}$ There may be no obvious means of escape from this current dilemma. ${ }^{129}$ It is technically possible, but certainly far from obvious, that seeking to prohibit private employer employment discrimination would, in practice, allow us to escape from

by making the pie the society produces larger . . . or . . . by obtaining a larger share . . of the social pie for its members. Our intuition tells us that the first method will rarely be chosen"); Andrei Schleifer \& Robert W. Vishny, The Grabbing Hand: Government Pathologies and Their Cures 81 (1998).

124. See Lindsey \& Teles, supra note 122, at 26; Schleifer \& Vishny, supra note 123, at 81.

125. See Lindsey \& Teles, supra note 122, at 18 ; Olson, supra note 123, at 47 ("when specialinterest groups become more important and distributional issues more significant, political life tends to be more divisive"); Robert Higgs, Ideology and Political Divisiveness, 11 INDEP. REV. 1, 1 (2018) See also id. at 2 (discussing the possible one-way "ratcheting effect" and realistic irreversibility of the overall results of such political processes).

126. See, e.g., Robert J. Gordon, The Rise and Fall of American Growth: The U.S. STANDARD OF LIVING SINCE THE CIVIL WAR 649 (2016) (unnecessary monopoly privileges and regulatory barriers to entry as contributing "to increased inequality while reducing productivity growth"); Lindsey \& Teles, supra note 122, at 18, 21; Jason Furman, Productivity, Inequality, and Economic Rents, PRO-MARKET (June 27, 2016), https://promarket.org/productivity-inequalityeconomic-rents; Asher Schechter, Nobel Laureates: Eliminating Rent Seeking and Tougher Antitrust Enforcement Are Critical to Reducing Inequality, PRO-MARKET (Jan. 10, 2017), https://promarket.org/nobel-laureates-eliminating-rent-seeking.

127. See the authorities cited supra note 126.

128. For background, see, e.g., Steven Kuhn, Prisoner's Dilemma (rev. version Aug. 29, 2014), http://plato.stanford.edu/entries/prisoner-dilemma. Classically, see ANATOL RAPAPORT \& ALBERT Chammach, PRISONER's DilemMa (1965).

129. See the sources cited supra note 128. Note that making unilateral concessions to one's opponents does not ordinarily lead to a generally appealing resolution of typical prisoner's dilemmas. 
these collectively unfavorable circumstances.

But it is impossible to understand either the costs or the benefits of trying to prohibit private employer job discrimination by looking exclusively to the personal or corporate interests at stake. Focusing on perceived interests is important, but there are important cultural elements involved that are not reducible to personal or corporate interests as well. For a fuller understanding, we must also consider what we might call the cognitive, knowledge-oriented, or epistemic virtues and vices embodied in a culture. It is to such matters that we now turn.

\section{PRIVATE EMPloyment Political Discrimination AND THE Role of EPISTEMIC VIRTUES AND VICES}

The quality of contemporary political discourse, within and beyond the private employee workplace, affects the value of attempting to prohibit private employer political discrimination. Not all political discussion, after all, is created equal, regardless of anyone's basic political sympathies.

The quality of our general political discourse is affected by both recognized elites and non-elites. Unfortunately, public trust and confidence in the words and deeds of many of our political and other cultural elites has generally diminished over time. ${ }^{130}$ A capacity of the elites for realistic self-appraisal and self-critique has, as well, not always been evident. ${ }^{131}$ Thus, for many persons, the quality and persuasiveness of elite political discussion has seemed disappointing. ${ }^{132}$

At the same time, the quality of political speech and debate among

130. For background, see Francis FukUyama, TRuSt: The Social ViRTUES AND the CREATION of Prosperity (1996). For more specific accounts, see, e.g., Christopher HAYEs, Twilight OF thE Elites: America After Meritocracy (2012); David Brooks, The Power Elite, The New York TIMES (Feb. 18, 2010) www.nytimes.com/2010/09/19/opinion/19brooks.html?em ("trust in elites has never been lower"); 2018 Edelman Trust Barometer Reveals Record-Breaking Drop in Trust in the U.S., at 1-2, (Jan. 22, 2018) www.edelman.com/news-awards/2018-edelman-trust-barometer ("[t]he collapse of trust in the U.S. is driven by a staggering lack of faith in government ... The remaining institutions of business, media, and NGOs also experienced declines of 10 to 20 points"); Richard D. Reeves, The Respect Deficit, (Aug. 8, 2018), at 9 https://aeon.co/essays/restoring-respect ("respect for 'the elite' among ordinary Americans has declined sharply in recent decades").

131. See Dean Burnett, Democracy v. Psychology, Why People Keep Electing Idiots, THE GuARDIAN (Apr. 2, 2015) www.guardian.com/science/brain-flapping/2015/apr/02/democracypsychology (describing politicians as themselves typically confident, but noting that the DunningKruger Effect links a lack of actual competence, in many respects, with confidence in one's abilities). For the Dunning-Kruger Effect itself, see Justin Kruger \& David Dunning, Unskilled and Unaware of It: How Difficulties in Recognizing One's Own Incompetence Leads to Inflated Self-Assessments, $77 \mathrm{~J}$. PERSONAlity \& Soctal PsYCH. 1121 (1999); David Dunning, The Dunning-Kruger Effect: On Being Ignorant of One's Own Ignorance, 44 ADvances EXPERIMENTAL Soc. PSYCH. 247 (2011). See also Marcin Zajenkowski et al., Why Do Angry People Overestimate Their Intelligence?, 70 INTELLIGENCE 12 (2018).

132. See the authorities cited supra notes $130-131$. 
non-elites in general has not seemed impressive either. Political discourse often seems intense, or even vitriolic, without being genuinely serious. Public confidence in the ability of fellow citizens to successfully engage in collective self-government has gradually faded. ${ }^{133}$ Political vehemence is not always founded on anything like an appropriate civic education, ${ }^{134}$ despite numerous educational reform efforts. $^{135}$

At the level of illustrative example, it is reported that only 26 percent of Americans surveyed could name all three branches of government. ${ }^{136}$ More than a third of Americans cannot tell what century saw the American Revolution. ${ }^{137}$ More than 40 percent cannot identify Auschwitz. ${ }^{138}$ And even at the university level, many students do not take a course in government, history, international affairs, statistics and probability, or economics. ${ }^{139}$ More broadly, the cultural habit of reading, in any technological format, has gradually been ebbing. ${ }^{140}$ Overall, the widespread loss of the habit of reading affects the quality and value of

133. See Peter Levine \& Kei Kawashima-Ginsberg, The Republic Is (Still) at Risk--and Civics is Part of the Solution (Sept. 21, 2017), www.civxnow.org/documents/v1/SummitWhitePaper.pdf/. See also David Blankenhorn, Where's the Trust?, THE AMERICAN INTEREST (Oct. 12, 2017) www.theamerican-interest.com/2017/10/12/where's-the-trust (referring to the "widespread and growing belief among Americans that many if not most of our fellow citizens lack basic honesty, integrity, and reliability").

134. See, e.g., Chester E. Finn, Jr., The Failure of Civics Education, Thomas B FordhaM INSTITUTE (Sept. 21, 2017), https://edexcellence.net/articles/the-failure-of-civics-education.

135. See id.

136. See Americans Are Poorly Informed About Basic Constitutional Provisions, ANNENBERG PUBLIC POLICY CENTER (Sept. 12, 2017), www.anmenbergpublicpolicycenter.org/americans-are-poorlyinformed. For discussion, see Dick Polman, An Ignorant America Endangers Democracy, WHYY (Sept. 13, 2017), https://whyy.org/articles/an-ignorant-america (noting that 33 percent of those surveyed were unable to name even one governmental branch, and that 37 percent were unable to name any First Amendment rights).

137. See Michael Curtis, Truth, Veritas, and Knowledge of History in the U.S., AMERICAN THINKER, at 1 (June 11, 2018), www.americanthinker.com/articles/2018/06/truth-veritas-andknowledge.

138. See id.

139. See, e.g., Derek Bok, The Crisis of Civic Education, THE CHRONICAL OF Higher EDUCATION 4 (Oct. 1, 2017), www.chronicle.com/article/The-Crisis-of-Civic-Education/241302/. Among other possible manifestations, current doubts as to a reasonably round Earth seem to be trending. See Stephanie Pappas, A Third of Young Millennials Are Confused About This Incontrovertible Fact, LIVE SCIENCE (Apr. 4, 2018), www.livescience.com/62220-millenials-flat-earth-belief.html.

140. See Christopher Ingraham, Leisure Reading in the U.S. Is at an All-Time Low, THE $\begin{array}{llllll}\text { WASHINGTON POST, } & \text { at } & 1 & \text { (June } & \text { 29, }\end{array}$ www.washingtonpost.com/news/wonk/wp/2018/06/29/leisure-reading ("[i]n 2004, roughly 28 percent of Americans age 15 and older read for pleasure on a given day. Last year, the figure was about 19 percent"). More elaborately, see Caleb Crain, Why We Don't Read, Revisited, THE NEW YoRkER (June 14, 2018), www.newyorker.com/culture/cultural-comment/why-we-dont-read-revisited (discussing the continuing reading decline). For some underlying educational achievement data, see 2015 Mathetics and Reading at Grade 12, The Nations Report Card www.nationsreportcard.gov/reading_math_g12_2015/. 
political discussion and debate. ${ }^{141}$

Generally, acquiring a minimally sufficient knowledge base and the ability to draw meaningfully upon that knowledge base in political discussion and debate require certain epistemic virtues. ${ }^{142}$ We may define epistemic virtue in parallel to moral virtue, with which epistemic virtue overlaps. ${ }^{143}$ An epistemic virtue refers to a trait or habit that directly promotes thinking and judging well. ${ }^{144}$

Political polarization, at high and increasing levels, may therefore reflect not only perceived interests and moral failings, but also a lack of epistemic virtues. Thus, certain versions of the idea of tolerance ${ }^{145}$ with respect to those who differ politically, within limits, can be a moral and an epistemic virtue. ${ }^{146}$ Of course, most people are not politically tolerant equally, or in all respects, toward all other political perspectives. ${ }^{147}$ Accordingly, it has been claimed with whatever exaggeration that today, everyone has a "Repugnant Cultural Other"148 on social media, ${ }^{149}$ and

141. Militance, vehemence, and implacability do not generally guarantee or substitute for insight. For a sense of some limited remedial measures in our context, see Cass R. Sunstein \& Reid Hastie, Making Dumb Groups Smarter, HARVARD BusINESS REVIEW (Dec. 2014) https://hbr.org/2014/12/making-dumb-groups-smarter; see also R. George Wright, Epistemic Peerhood in the Law, 91 ST. JoHN's L. REV. 663 (2018).

142. For background, see John Turri, Mark Alfano \& John Greco, VIRTUE EPISTEMoLogY (rev. ed. Nov. 7, 2017), https://plato.stanford.edu/entries/epistemology-virtue. See also Alan Jacobs, How To THINK (2017); Robert C. Roberts \& W. Jay Woods, INTELLECTUAL VIRTUES: AN ESSAY IN Regulative Epistemology ch.10 (2009); Heather Battally, EPISTEMic SElF-INDUlgence, in VIRTUE AND VICE, EPISTEMIC AND MORAL 215 (Heather Battally ed. 2010); Wayne Riggs, Open-Mindedness, id. at 173 .

143. Thus, while someone might have the "courage of their convictions," a kind of courage is also required to expose a personally preferred belief about the world, in which one has invested, to genuine challenge. For an exceptional example, see Bertrand Russell's account of the intellectual integrity of philosopher Gottlob Frege, as reported in Thomas Tymoczko, New DiRECTIONS IN THE PHILOSOPHY OF Mathematics 6 (rev. ed. 1996). An opposed epistemic vice might involve, for example, a knowing indulgence of one's own confirmation bias in seeking and assessing evidence on political questions. See Raymond S. Nickerson, Confirmation Bias: A Ubiquitous Phenomenon in Many Guises, 2 REv. GEN. Psych. 175 (1998). See also Dan Kahan, What is Motivated Reasoning and How Does It Work?, SCIENCE + RELIGION TODAY (May 4, 2011) www.scienceandreligiontoday.com/2011/05/04/what-ismotivated-reasoning.

144. See the authorities cited supra note 142. Thus, one might think of appropriate forms of intellectual honesty, integrity, open-mindedness, patience, conscientiousness, and so forth as epistemic virtues.

145. But see Robert Paul Wolff, BARRington MOORE, JR. \& Herbert MARCUSE, A CRITIQUE of Pure TOLERANCE (1965).

146. See Jean M. Twenge, IGen: Why Today's Super-Connected Kids ARE Growing Up LESS REBELLIOUS, MORE TOLERANT, LESS HAPPY--AND COMPLETELY UNPREPARED FOR ADULTHOOD ch. 9 (2017) (Simon \& Schuster Inc. 2017) (Interview and Survey data; racial, sexual, and gender tolerance and inclusion among post-Millennials).

147. See, e.g., April Kelly-Woessner, Trade Protection in the Marketplace of Ideas, Heterdox Academy (May 18, 2016), https://heterodoxacademy.org/trade-protectionism. More contentiously, see Ben Cohen, Generation Z: The Intolerant Ones, (July 27, 2018) www.jamesgmartin.center /2018/07/generation-z-the-intolerant-ones.

148. JACOBS, supra note 142, at 27. 
that "many Americans are happy to treat other people unfairly, if those other people belong to the alien Tribe." 150

The problem is that often, the dismissal of politically unappealing beliefs reflects not an epistemically, virtuously conducted inquiry, but an insufficiency of "civic awareness and political knowledge."151 Indulgence in the epistemic vices, such as impatience, inconsistency, confirmation bias, ${ }^{152}$ chronic groupthink, ${ }^{153}$ and the ego-defensive mechanisms classically described by Anna Freud ${ }^{154}$ contribute further to the problems of political ignorance and polarization.

There are also, however, limits to the value of focusing on individual or even group epistemic virtues and vices. The failure of educational and other institutions to impart political knowledge may also contribute to political intolerance. ${ }^{155}$ Increased political polarization may as well reflect an increasing exhaustion of a society's capacity for resolving obvious structural problems. ${ }^{156}$ Societal exhaustion in this respect may lead to popular disillusionment, which leads to further political polarization. ${ }^{157}$ Polarization becomes further self-sustaining and selfexacerbating as persons who dislike political polarization increasingly self-select out of political discussion. ${ }^{158}$

These structural or institutional processes then interact with epistemic virtues and vices when political polarization becomes not merely a religion-substitute, ${ }^{159}$ but a religion-substitute that is distinctly hostile to

\section{See id.}

150. Id. at 73 .

151. Kelly-Woessner, supra note 147, at 2. See also Ross Douthat, Free Speech Will Not Save Us, THE New YoRK TIMEs (May 26, 2018) www.nytimes.com/2018/05/26/opinion/sunday/free-speech-nflprotests-trump.html ("tolerance and magnanimity are virtues that our society's warring factions need to cultivate. But ... these virtues depend on deeper forms of wisdom and consensus, and they can't always sustain themselves in cultures that are simply going bad.").

152. See Nickerson, supra note 143.

153. See, e.g., Robert S. Baron, So Right It's Wrong: Groupthink and the Ubiquitous Nature of Polarized Group Decision Making, 37 AdVAnces ExPERIM. Soc. Psych. 219 (2005); Conor Friedersdorf, How People Like You Fuel Extremism, THE ATLANTIC (June 27, 2017) www.theatlantic.com/politics/archive/2017/06/together-people-like-you-fuel-extremism at 4.

154. See generally Anna Freud, THE EGO AND tHe MEChanISMS OF DEFENSE (rev. ed. 1967).

155. See Kelly-Woessner, supra note 147 , at 2.

156. See Olson, supra note 123, at 42; Jonathan Rauch, How American Politics Went Insane, THE ATLANTIC (Jul/Aug. 2016) www.theatlantic.com/magazine/archive/2016/07/how-american-politicswent-insane at 5 .

157. See Tom Jacobs, The Emotional Roots of Political Polarization, PACIFIC STANDARD (Feb. 14, 2018), https://psmag.com/news/emotional-roots-of-political-polarization.

158. See Conor Friedersdorf, Why Everything Is Politicized Even Though Most Americans Hate It, THE ATLANTIC (Mar. 26, 2013) www.theatlantic.com/politics/archive/2013/03/why-everything-ispoliticized at 4 .

159. For a controversial discussion, see Brad Hirschfield, Democrats Are More Dogmatic Than Republicans . . . When Dating, http://thewisdomdaily.com/democrats-are-more at 3 ("politics has become the new religion of millennials and Gen Xers"). For evidence of decline of the traditional 
many outsiders. ${ }^{160}$ Mere occasional anger may well be resolved by reconciliation. But group contempt of the sort associated with increasing political polarization often involves sustained hostility. ${ }^{161}$

\section{Conclusion: Is Political Discrimination In THE PRIVATE WORKPLACE PROPERLY SUBJECT TO LEGAL REDRESS?}

Legal restraints on politically based discrimination by private employers is, at least for the moment, still more the exception than the rule. ${ }^{162}$ But there is certainly enough evidence of the adverse consequences of some forms of political discrimination by private employers to raise serious concerns. ${ }^{163}$ Any adverse employment decision adopted for extraneous, self-indulgent, or irrelevant reasons should be disturbing. And there is certainly evidence that the quality of corporate group decision making can often be enhanced by cultivating the expression of different perspectives. ${ }^{164}$

It is possible to gain some of the benefits of a viewpoint-diverse workforce by explicitly incentivizing some persons to forcefully and carefully express contrarian views those persons do not necessarily

American religious denominations, see Robert D. Putnam \& David E. Campbell, AMERICAN GraCE: How RELIGION DIVIDES AND UNITES Us (2016); Allen Downey, The U.S. Is Retreating from Religion, SCIENTIFIC AMERICAN (Oct. 20, 2017), https://blogs.scientificamerican.com/observations/the-us-isretreating-from-religion.

160. See Arthur C. Brooks, Bipartisanship Isn't for Wimps, After All, THE NEW YORK TIMES (April 9, 2016) www.nytimes.com/2016/04/10/opinion/bipartisanship-isnt-for-wimps-after-all.html at 3.

161. See id.

162. See infra Section II. We again set aside cases of private university faculty employment and cases of private employers with an obviously essential pre-established political mission. See supra note 1.

163. See supra Sections III.-IV.

164. See Katherine W. Phillips, How Diversity Makes Us Smarter, SCIENTIFIC AMERICAN (Oct. 1, 2014), www.scientificamerican.com/article/how-diversity-makes-us-smarter; Katherine W. Phillips et al., Better Decisions Through Diversity, KELLOGG InsIGHT (Oct. 1, 2010), https://insight.kellogg.northwestern.edu/article/better_decisions_through_diversity; Margolis, When Politicians Determine Your Religious Beliefs, NEw YORK TIMES (July 11, 2018) www.nytimes.com/2018/07/11/opinion/religion-republican-democrat.html at 4 ("hearing diverse political messages promotes tolerance, interacting in politically integrated settings curbs partisan biases, and having key social groups represented in both political parties helps maintain civil political discourse"); Cass R. Sunstein \& Reid Hastie, Making Dumb Groups Smarter, HaRvard Business REVIEW (Dec. 2014) https://hbr.org/2014/12/making-dumb-groups-smarter at 14 ("[t]o function well, groups need to take advantage of cognitively peripheral people") (i.e., those persons holding relatively rare information and perspectives, as distinct from information and perspectives already widely shared by the decision making group); Michel Zaitouni \& Amani Gaber, Managing Workforce Diversity From the Perspective of Two Higher Education Institutions, 18 INT. J. BUS. P. MGMT. www.inderscienceonline.com/doi/pdf1.0.1594. There is some overlap between these findings and the adverse effects of 'groupthink.' See supra note 153 and the classic exposition Irving L. Janis, Groupthink: Psychological Studies of Policy Decisions and Fiascoes (2d ed.1982). 
hold. ${ }^{165}$ But it is also possible that such techniques do not fully substitute for hearing the relevant arguments from persons, in our case fellow employees, who genuinely believe them. This was classically argued, at least for the broader political forum, by John Stuart Mill. ${ }^{166}$ Mill argued in particular that one who pursues truth should do more than merely:

hear the arguments of adversaries from his own teachers, presented as they state them, and accompanied by what they offer as refutations. . . He must be able to hear them from persons who actually believe them and who defend them in earnest and do their very utmost for them. He must know them in their most plausible and persuasive form."167

Mill, however, also clearly values the quite different ability of persons to throw themselves "into the mental position of those who think differently from them." 168

Thus, the added value to organizational decision-making of hearing political arguments from genuine believer-employees, even assuming their candor, is unclear. And even in an era of increasing corporate politicization, ${ }^{169}$ the significance of corporate political decisions that are really meaningfully open to ordinary employee influence may be limited. ${ }^{170}$ Corporate political decisions may reflect the corporation's political culture. ${ }^{171}$ However, that culture may be shaped far less by current ordinary employees than by the highest managerial levels, shareholders, outside political pressures, customers, desired customers, or by the broader culture itself. ${ }^{172}$

It is possible that some politically-based workplace friction, awkwardness, and lost productivity would be avoided by legal rules forbidding political discrimination in the private workplace. ${ }^{173}$ But, in general, there are obvious alternative ways to address such problems in the workplace. Incentives for a politically mutually compatible workplace may take many other forms, including informal sanctions, on- and off-site morale building, or focused training.

165. See Sunstein \& Hastie, supra note 164 , at 14 (discussing "devil's advocacy" and "red team" mechanisms for testing institutionally popular beliefs and judgments).

166. See John Stuart Mill, ON LJBERTY ch. 2, at $98-99$ (Gertrude Himmelfarb ed., 1974).

167. Id. at $98-99$.

168. Id. (thereby allowing one, ironically, to really understand one's own view for the first time).

169. See supra Section III.

170. See supra notes 89-91 and accompanying text.

171. See supra note 98 and accompanying text.

172. See supra note 90 and accompanying text.

173. See supra Sections III. - IV. and the authorities cited supra note 75, in particular. 
More importantly, attempting to enforce legal rules against political discrimination in the private workplace would generate unintended but foreseeable adverse consequences. For one, the crucial distinction between employee speech that is in the relevant sense "political" and employee speech that is not "political" will have boundaries requiring constant judicial maintenance and supervision. Then there would be the problem of which instances of employee speech do and d0 not reflect, to some minimally legally sufficient degree, on the employer. Additionally, there is the question of how much weight to give to the employer's claim that the effect of the employee's speech on the employer was, either internally or externally, sufficiently adverse to justify the employment decision taken. Even then, for reasons of public policy, we may wish to give either an absolute or qualified privilege, or some other sort of legal protection, to some instances of private employee political speech. ${ }^{174}$

We would also have to settle on some specific legal test for the new right, ranging from something like a mere reasonableness test, to European balancing ${ }^{175}$ and possible subordination, ${ }^{176}$ to some version of either strict or exacting scrutiny. ${ }^{177}$ Relatedly, we would have to decide whether generally politically popular speech by employees should be treated the same as generally politically unpopular speech, by ordinary citizens.

All these practical considerations would admittedly have to factor in any harms that result from an employer's ability to use political disagreement with an employee as a pretext for clearly prohibited discrimination on grounds such as race, ethnicity, sex, or sexual orientation. ${ }^{178}$ We can certainly imagine such cases. But the most important racial and other categorical employment discrimination cases presumably involve something like informal bars, quotas or quasiquotas, or statistically evident discrimination across a number of cases. ${ }^{179}$ Current employees can often be more discreet or adaptive in matters of genuine political belief than in matters of, say, one's race or gender, even in cases of employer intrusiveness. ${ }^{180}$ And the political

174. Consider, for example, private employee political speech that resembles important public employee whistle-blower speech, or where disciplining a private employee for political speech clearly violates some fundamental public policy.

175. See supra notes 54-60 and accompanying text.

176. See id.

177. See, e.g., R. George Wright, A Hard Look at Exacting Scrutiny, 85 UMKC L. REV. 207 (2017)

178. See supra note 78 and accompanying text.

179. See, e.g., Griggs v. Duke Power Co., 401 U.S. 424 (1977)

180. Clicking on an employer's political rant is only minimally more time or attention consuming than deleting it unread. 
preferences of many job applicants may not be known to employers at the time of hire. ${ }^{181}$ In any event, any such pretextual case, in which race or gender discrimination is disguised by a claim about political differences, can be argued to be indeed pretextual, or at the very least, a mixed-motive case. ${ }^{182}$

Interestingly, it would be difficult to predict whether a rule against private employer discrimination on political grounds would generally advantage one general political perspective or another. Employers at this point differ in their political perspectives, and in the intensity thereof, ${ }^{183}$ and the general vector of corporate politicization overall can evolve over time. ${ }^{184}$ In this sense, it would be difficult to say what the overall longterm political impact of a rule against private employer political discrimination would be.

But some effects of any such rule are, at a more specific level, reasonably predictable. Let us again set aside deservedly exempt employers. ${ }^{185}$ Presumably the most significantly affected private employers would be those with a substantial and readily identifiable corporate political atmosphere, if not an explicit political agenda, at whatever point on any political spectrum, on one or more political issues. Toward the extremes, predictably, there would be corporate employers who would view a legal requirement of political nondiscrimination as not merely distasteful, but abhorrent.

Perhaps it would tend to be the relatively politically militant corporate employers who might benefit most from responsible employees with politically dissident views. ${ }^{186}$ But the employers in such cases are typically already keenly aware of the existence of relevantly dissenting views. ${ }^{187}$ And such relatively committed employers, of whatever political outlook, would presumably be the most inclined to seek to evade any such employment discrimination rules. For such an employer, it will be possible to argue that any conspicuous political dissenter is disrupting the subtle, informal operation of the workplace, and thus

181. Employees and potential employees presumably have a number of privacy and accessibility options for their social media accounts.

182. See the authorities cited supra note 73 .

183. See supra notes $90-99$ and accompanying text.

184. For example, companies such as Delta Airlines were once willing to offer discounts to National Rifle Association member. See supra note 99.

185. See supra note 1 .

186. See supra the authorities cited at notes 141,153 , and 164 .

187. We may reasonably assume, for example, that corporate employers are typically aware of the most prominent general objections to their views, or else that they would be disinclined to change their political views based in particular on challenges posed by dissenting employees. But see supra notes 164-172 and accompanying text. 
imposing costs in sheer workplace productivity and efficiency. ${ }^{188}$ Less politically valenced employers may not make such arguments to the same extent. But less politically valenced employers are also less likely to discriminate on the basis of politics to begin with.

It is thus fair to conclude that even if, in some abstract sense, a general rule against private employer political discrimination against employees and job applicants promised some benefits, the costs of adopting and seeking to implement such legal rules under our current cultural circumstances would outweigh those likely benefits. And under other cultural circumstances, any such rules would have less work to do.

More positively, we might consider John Stuart Mill's recognition that a just society may allow even "very severe penalties" 189 of an associational, rather than a legal, sort ${ }^{190}$ without legal redress. Thus, for personal reasons, we may prefer to associate with generally like-minded others for whom we have greater respect, ${ }^{191}$ not in order to restrict anyone's liberties, but in the legitimate exercise of our own. ${ }^{192}$

Of course, there are obvious limits to the scope of any such private employment associational freedom. Many categories should be protected against employment discrimination. Perhaps a key distinction is that we obviously do not have public discussions over whether individuals or groups should somehow effectively change their race, ethnicity, sex, sexual orientation, age, disability status, religion, or other typically legally protected status. No particular race or gender, in general, is thought to be an aspirational goal for others. In sharp contrast, though, much of the traffic on social media and in educational institutions assumes that change in a person's political beliefs or political party affiliation is possible and often appropriate. With matters of political belief and affiliation, our best option would be to generally allow for some like-minded association, while also allowing ample room for the various techniques of political persuasion to have their proper scope.

188. See, e.g., Google Corporation, supra note 71 and accompanying text.

189. See John Stuart Mild, On Liberty ch. 2, at 98-99 (Gertrude Himmelfarb ed., 1974).

190. See id. at 86-87.

191. See id. at 86.

192. See id. Mill's basic logic in this regard is pursued in H.L.A. HART, LAW, LIBERTY, AND MORALITY 76-77 (1963) (discussing moral persuasion as distinct from legal requirement). 
